\title{
Disparity in Criminal Sanctions in Criminalizing Corruption Cases
}

\author{
Junjungan Moses Siallagan ${ }^{1}$, Ediwarman ${ }^{2}$, Madiasa Ablisar ${ }^{3}$, Muhammad Ekaputra ${ }^{4}$ \\ ${ }^{1234}$ Faculty of Law, Doctoral of Law Program, University of North Sumatra, Medan, Indonesia. \\ Email: junjunganmosessiallagan@gmail.com,profediwarman@gmail.com, ablisar@yahoo.co.id, \\ moh.ekaputra@gmail.com
}

\begin{abstract}
Criminal disparities in court judges decisions are in principle a natural thing, with the independence of the court as stipulated in Law Number 48 of 2009 concerning Judicial Power. However, if the criminal disparity is too glaring, then the decision is seen as unfair to the convict. This normative juridical research discusses what are the factors that can lead to a conspicuous criminal disparity in corruption cases handed down by court judges. Offering alternative solutions in the future so that the glaring criminal disparity can be minimized. It was concluded that the factors that led to the glaring criminal disparity in court decisions for corruption cases, caused by differences in the thoughts and schools of court judges regarding the purpose of sentencing, there is too broad freedom of court judges, discretionary factors, and legal interpretation authority. So that the court judges in imposing the amount of crime on the defendant are too free and broad in determining the amount of crime that will be served by the defendant of corruption. It is hoped that there will be no glaring disparities in the imposition of criminal cases of corruption, countries need to consider making a table of criminal guidelines. The range of the number of crimes that may be imposed on defendants for similar corruption cases and the level of seriousness must be regulated should be regulated. So that the existence of these sentencing guidelines can control the freedom of judges which is too broad, so that glaring criminal disparities can at least be minimized to fulfill a sense of justice for convicts of corruption.
\end{abstract}

Keywords: disparity, crime, punishment, and corruption.

\section{INTRODUCTION}

Justice has always been an issue of debate in sentencing, questioning the value of the community's sense of justice even though justice is relative. The issue of criminal disparity in sentencing is in principle reasonable because of the existence of an independent judicial authority. However, when the criminal sanctions imposed by the judge on the defendant are very conspicuous, then the decision is seen as an unfair decision.

Sentencing in corruption cases becomes interesting because it is possible for court judges to impose different criminal sanctions even though the articles and criminal acts are the same. Judges have very broad freedom to determine the amount of criminal sanctions for the accused.[1] This can lead to negative excesses against the convicts, justice seeker, and society about the application of the values of a sense of justice.

Corruption is indeed an extraordinary crime, the main enemy of society and all nations, [2] broad impact, detrimental to the people and the country.[3] But the value of a sense of justice must still be upheld in sentencing. Every decision made by a judge must be proportional based on philosophical, sociological, and juridical considerations.[4] The principle of proportionality in imposing criminal sanctions on defendants of corruption is important for judges to provide a sense of justice so that there is no glaring criminal disparity.

Court judges may not decide cases based on opportunity, or prejudice, or ambition to punish severely to provide a mere deterrent effect, or not based on proper/weak and proportional arguments.[5] All parties are ordered to respect the court's decision and must accept it because it has been decided by a court judge who must be trusted and competent for it. Meanwhile, critical thinking does not fully believe in what the judges decide because politicization often colors the nuances of law enforcement.[6]

Fair punishment is needed so that racism, discrimination and disparity can be reduced. Sentencing must be consistent (legal certainty), fair, beneficial, and economical.[7] The imposition of a criminal must look at many factors and not only look at the law and punish severely.[8] 
Judge's decision based on legal considerations in accordance with facts, laws, and belief without being influenced by external and internal intervention is a judge's decision that is qualified and professionally accountable.[9] Only judges who have ideals have a call of conscience and are able to produce quality decisions.

However, the judge in imposing criminal sanctions has the potential to cause individualization because of the freedom of the court. The judges are free to choose the amount of punishment to be imposed on the accused of corruption, whether heavy or light, based on the principle of freedom. The judge's freedom is considered too broad because it is not limited in the laws and regulations. or in sentencing guidelines so as to open up opportunities for judges to impose a number of conspicuous criminal sanctions in their decisions.

In relation to the disparity in sentencing in corruption cases handed down by court judges, then the problem discussed in this paper is what are the factors that cause the conspicuous criminal disparity in court decisions on corruption cases and how efforts should be made to minimize the occurrence of criminal disparities in court decisions.

The occurrence of this glaring disparity in criminal sanctions in the sentencing of corruption cases certainly creates a sense of injustice for the community and jeopardizes legal certainty for justice seekers, especially convicted criminals. This situation can also have a negative impact on the use of the principle of certainty in the Indonesian legal system and reduce public confidence in the law and law enforcement.

\section{METHODOLOGY}

This type of research method is normative, using secondary legal materials, and empirical approach. The primary legal material is the 1945 Constitution of the Republic of Indonesia, the Criminal Procedure Code, Law Number 48 of 2009 concerning Judicial Power, and Law Number 31 of 1999 in conjunction with Law Number 20 of 2001 concerning the Eradication of Corruption.

\section{RESULTS AND DISCUSSION}

\subsection{Definition of Disparity in Criminal Sanctions}

The meaning of criminal disparity on the one hand can be criminalized against someone but on the other hand can also be released. This certainly endangers the principle of legal certainty.[10] The disparity of criminal sanctions concerns the application of unequal criminal sanctions to the same crime or to criminal acts of different nature without a clear justification.[11] This can occur in the punishment of the perpetrators who commit an offense together without appointing a legal category.[12] Can occur in the difference in additional criminal penalties in the form of Replacement Money.[13]
The sentencing of a crime by a judge can rely on subjective considerations and will certainly result in differences in the sentencing of criminals against the same case. Disparity is a form of imbalance, difference in quantity and quality between two or more things.[14] Criminal disparity is a difference in treatment or outcome that does not come from legal considerations.[15]

Disparity in sentencing is a difference in the sentencing of criminal cases for cases of similar or equivalent seriousness, without a clear reason or justification. Disparity also occurs when several perpetrators with the same crime are given different criminal decisions. Criminal decisions are applied differently to two criminals whose offenses are identical. Identical means that the criminal records of both are the same, but got a very different verdict.[16]

The disparity in the imposition of criminal sanctions can result in people not trusting judges for the application of the principle of equality before the law, convicts who are sentenced to more severe punishments become angry and resistant to the coaching system in correctional institutions, and can reduce public confidence in law enforcement.[17]

\subsubsection{Corruption Cases Containing Shocking Criminal Disparities}

In fact, in the system of law enforcement against perpetrators of corruption, there is a tendency in imposing criminal, namely the disparity in the number of criminal sanctions that are striking in the decisions of court judges in Indonesia.

There is a criminal disparity in corruption cases handed down by judges. Like Gayus HP Tambunan was convicted by South Jakarta District Court 7 years in prison, a fine of Rp.300.000.000, and 3 months in prison.[18] The judge of the Jakarta High Court handed down a criminal sentence of 10 years in prison, a fine of Rp.500.000.000, and 4 months in prison.[19] The judge of the Supreme Court handed down a criminal verdict of 12 years in prison, a fine of Rp.500.000.000, and an additional 6 months in prison.[20]

Each judge at the court level imposes different penalties according to their freedom of trial. A striking disparity exists between the decisions of the judges of the South Jakarta District Court and the Supreme Court with a difference of 5 years. The Supreme Court sentenced 12 years in prison, a fine of Rp.500.000.000, and a substitute sentence of 6 months in prison.

A glaring criminal disparity is also found in the case of Eep Hidayat bin P. Oeking (Former Regent of Subang Regency, West Java). The Bandung District Court ruled acquittal.[21] However, the Supreme Court instead decided to be sentenced to 5 years in prison, a fine of Rp.200.000.000, an additional 3 months in prison, and a replacement money of Rp.2.548.465.160.[22]

Angelina Patricia Pingkan Sondakh was sentenced to prison for 4 years and 6 months and a fine of 
Rp.250.000.000, provided that if the fine is not paid, it is replaced with imprisonment for 6 months.[23] The Supreme Court instead handed down a sentence of 12 years imprisonment, a fine of Rp.500.000.000, with an additional fine of 8 months in prison, replacement money of Rp. 12.580.000.000, and US \$ 2.350.000, with an additional penalty of replacement money, namely imprisonment for 5 years.[24]

Striking disparities occur in the corruption case of Syahril Sabirin. The Central Jakarta District Court sentenced him to 3 years in prison, a fine of Rp.15.000.000, and a substitute sentence of 3 months imprisonment.[25] Jakarta High Court acquitted the defendant.[26] The Supreme Court sentenced 2 years in prison, a fine of Rp.15.000.000, and a substitute sentence of 6 months in prison.[27]

A striking disparity also occurred in the case of Rokhmin Dahuri. The prosecutor's demands are 6 years in prison, a fine of Rp. 200,000,000, - and a substitute sentence of 4 months in prison. The Central Jakarta District Court sentenced 7 years in prison, a fine of Rp. $200,000,000$, - and a substitute sentence of 6 months in prison.[28]

Judge at the Jakarta High Court upheld the decision of the Central Jakarta District Court.[29] The judge of the Supreme Court ruled that the defendant was acquitted. While the judge on review decided that the defendant was proven guilty and convinced that he had committed corruption with a sentence of 4 years and 6 months in prison, a fine of Rp.200.000.000, and a substitute sentence of 4 months in prison.[30]

\subsection{Factors Effecting the Occurence of Striking Criminal Disparities}

Many factors cause criminal disparity.[31] The factors that cause the disparity in the imposition of criminal sanctions are striking in corruption cases, among others because: (1) differences in understanding of the philosophy of punishment; (2) independent judicial authority that is too free; (3) lack of understanding of legal interpretation; (4) discretion; (5) depletion of morality; and (6) the absence of guidelines for imposing criminal penalties.

\subsection{Differences in Philosophy / Philosophy of Sentencing}

Differences in philosophy / philosophy of punishment lead to criminal disparities.[32] The imposition of criminal sanctions is sometimes the result of instinct between one judge and another judge.[33]

The purpose of the philosophy of punishment in retributive theory is different from the relative goal. Retributive theory aims to retaliate against the perpetrators of crime.[34] It does not at all consider efforts to repair and foster prisoners, but how to keep the criminal law directed as appropriately as possible to be imposed in accordance with the level of crime committed.[35]
Relative theories in punishment, such as deterrence theory, treatment theory, social defense theory, and restorative theory, attempt to improve the situation from a different point of view. In the theory of prevention, punishment is to make someone feel afraid and refrain from committing a crime or trying to do prevention.

If judges are oriented towards the philosophy of treatment theory, then the purpose of punishment is directed at efforts to treat or repair the perpetrator, not to his actions. Examines the character of the actor from the point of view of biology, psychology, and sociology, and the object of analysis is the actor, not the action. The perpetrator is seen as a sick person so that treatment and corrective actions are needed.[36]

The penal philosophy of social order theory, directing punishment for efforts to improve and protect the community. Integrating individuals into social order and not punishment for their actions.[37]

Sentencing in restorative theory is not to satisfy the absolute demands of justice. Retaliation itself has no value, but is a means of protecting society. Criminal law is aimed at upholding the rule of law, protecting the legal community.[38]

If between the panel of judges there are differences in the philosophy of punishment, then what will happen is a dissenting opinion in adjudicating the case. This difference of opinion will result in a glaring disparity in the imposition of criminal sanctions.[39] A judge does not dare to disagree with his colleague because his colleague is a senior judge so the tolerance is quite strong.[40]

\subsection{The Law Determines the Elements of the Judge's Confidence}

Criminal procedural law adheres to the theory of evidence according to the law in a negative way. According to Article 183 of the Criminal Procedure Code, a court judge may not impose a sentence on a person unless there is at least two pieces of evidence, and the judge is convinced of the defendant's guilt. Based on this provision, difficult to prevent the occurrence of glaring criminal disparities, because the element of judge's conviction is quite prominent and the freedom is very wide to choose the number of criminals.[41]

To declare the guilt or innocence of a defendant and determine the appropriate amount of punishment for the perpetrator, it is not enough to be based on the judge's conviction or based only on evidence according to the provisions and method of proof using evidence determined by law.[42]

The existence of an element of judge's belief in convicting perpetrators of criminal acts of corruption opens up opportunities for their freedom to be used in imposing crimes against perpetrators. Although still observing the law, but the element of the judge's conviction also greatly determines the occurrence of criminal disparities in sentencing. 
Court judges should combine objective and subjective elements in imposing a sentence. If one of the two elements is not met in determining the guilt of the defendant, the alleged guilt is not proven. On the other hand, if there is sufficient evidence of the defendant's guilt, but the judge is still not convinced of the error, the defendant may be acquitted.

\subsection{The Court's Independent Authority is Too Free}

Court independence cannot be influenced by anyone other than the judge.[43] Court independence emphasizes the freedom of judges / independence of judges in the judiciary.[44] Also referred to as judicial power, namely the authority of judges to determine the application of legal norms to cases submitted to them.[45]

Law Number 48 of 2009, regulate the independence of the court. Judicial power is the power of an independent state to administer justice to uphold law and justice based on Pancasila and the 1945 Constitution, for the sake of the rule of law. The judicial independence powers regulated in this law are too broad. There is no limit for judges regarding the severity of the criminal sanctions to be imposed, unless it is based on his belief.

\subsection{Lack of Understanding of Judges on Legal Interpretation}

The lack of knowledge of judges to interpret or interpret the law, is also seen as a factor that gives rise to criminal disparities in decisions. It is not uncommon for inexperienced judges, especially young judges, to not understand the interpretation of the law. Judges tend to be rigid when interpreting the law into concrete situations. So sometimes the judge's decisions are inconsistent with each other.

\subsection{Court Judge's Discretion}

Another factor that has the potential to cause a glaring criminal disparity is the judicial discretionary authority. The source of the disparity in imposing criminal charges is the difficulty of conquering judges' discretion.[46] Discretion is the authority given by law to act in certain conditions or situations in accordance with the considerations of official officials to give judgments based on the call of conscience.[47]

Discretion involves making decisions that are not bound by law, rather it depends on personal judgment.[48] Discretion is a call of conscience. Therefore, in the application of discretion, it should be wise with a moral approach, not a formal approach.[49]

\subsection{The Morality of the Court Judges}

The next factor that has the potential to cause a glaring criminal disparity is the morality of judges. Legal doctrine views that law enforcement is poor because it is not supported by the personal morality of law enforcement officers.[50] Morality emphasizes ethical behavior rather than the human state of mind which consists of actual standards applied in life.[51]

Morality as an important principle in law enforcement. Judges do not only apply written law but must be based on values that grow and develop in society. The written law must be balanced with morals as a call to conscience based on the nature of divinity. People who obey God can control their actions from unethical (immoral) actions.

\subsection{Judicial Institutions In Indonesia Do Not Yet Have Criminal Guidelines}

The next factor that can cause a glaring criminal disparity is that there are no sentencing guidelines. Although Indonesia already has Law Number 48 of 2009 , but does not set limits for judges regarding the severity of criminal sanctions that may be imposed.

For example, in the United States, the Sentencing Commission is a commission that is authorized to make criminal guidelines.[52] The sentencing table guidelines determine the number of criminal sanctions that may be imposed by court judges as a sentencing guideline applicable in the states.[53]

In the table of punishment guidelines in the federal state, it is divided into four zones, namely zone A, zone $\mathrm{B}$, zone $\mathrm{C}$, and zone $\mathrm{D}$. With the division of the zone, it means that there are only four groups / zones that are allowed for judges to impose criminal penalties based on the number of crimes. For example, zone A for the number of crimes can only be imposed by judges from 0 years to 1 year in prison, and so on.[54]

Criminal guidelines in the United States have reduced criminal disparities. For example, in the state of Minnesota, which evaluated the application of the sentencing guidelines, it concluded that the disparity in sentencing has decreased since the enactment of the sentencing guidelines. The reduction in criminal disparity is indicated by the increase in uniform and proportional criminal penalties. [55]

Sentencing guidelines are an alternative as signs for judges, and still refers to the independence of the court.[56] Can reduce criminal disparities, encourage the creation of a common perspective of judges in viewing a crime, make it easier for judges to make decisions make it easier for the public to see whether the judge has considered certain things or not, and at the same time as a control over the judges in exercising their freedom.[57]

\subsection{The Attorney General's Has Guidelines for Prosecuting Corruption Cases}

The Attorney General's Office in Indonesia already has specific prosecution guidelines for corruption cases. The aim is to avoid disparity in demands between one prosecutor and another in handling corruption cases. This is regulated in the Attorney General's Circular 
Number: SE-003/A/JA/2010 Regarding Guidelines for Criminal Prosecutions in Corruption Crimes.

The disparity of prosecution is the difference in the number of criminal charges demanded by one prosecutor and another with the same locus delicti case. For the same locus delicti corruption case at all levels of the court, the substance of the indictment and the number of charges are fixed, and the prosecutor also remains the same person for the case at hand. This means that the demands will not change (fixed) between what is demanded at the District Court level, High Court, and the Supreme Court.

\section{CONCLUSIONS AND RECOMMENDATIONS}

Many factors cause the disparity in imposing criminal sanctions that are striking in corruption cases, such as differences in the judges' understanding of the philosophy of punishment in retributive theory and relative theory. If you adhere to the retributive theory, the judge looks at the aspect of error so that the perpetrator must be punished severely, but if you follow the relative theory, then the judge will look at the aspects of the perpetrators so that improvements are needed, maintenance, recovery, or legal protection. In addition, because the law determines the judge's conviction, judicial independence authority that is too free, lack of understanding of legal interpretation, judicial discretion, morality of court judges, and there are no criminal guidelines. All of these factors influence each other, therefore, so to avoid the occurrence of a glaring criminal disparity in corruption cases, it is better to make a table of sentencing guidelines for court judges that contains limits on the number of criminal sanctions that may be imposed by court judges.

\section{ACKNOWLEDGMENTS}

This research was partially support by our advisor are Professor Ediwarman, Professor Madiasa Ablisar, and Doctor Muhammad Ekaputra, and students of the doctoral program of law in University of North Sumatra.

\section{REFERENCES}

[1] Muladi, Hal-Hal Yang Harus Dipertimbangkan Hakim Dalam Menjatuhkan Pidana Dalam Rangka Mencari Keadilan Dalam Kapita Selekta Sistem Peradilan Pidana, (Semarang: Badan Penerbit Universitas Diponegoro, 1995), p. 170.

[2] Marwan E., "Pengadilan Tipikor", Lokakarya, Anti-korupsi bagi Jurnalis, Surabaya, 2007, p. 1.

[3] Kimberly A.E., Korupsi \& Ekonomi Dunia, (Jakarta: Yayasan Obor Indonesia, 1999), pp. 1-2.

http://news.detik.com/read/2011/09/19/124412/ 1725346/10/vonis-koruptor-rendah-ketua-mahakim-punya-pertimbangan- sendiri?n990102mainnews, diakses tanggal 21 September 2021.

[5] Michael T., Sentencing Matters, (Oxford: Oxford University Press, 1996), p. 5.

[6] Ibid.

[7] Ibid., p. 4.

[8] Ibid.

[9] http://www.antikorupsi.org/id/content/kualitasputusan-hakim-harus-didukung-masyarakat, diakses tanggal 21 September 2021.

[10] Marwan E., "Apakah Suatu Kebijakan Dapat Dikriminalisasi? (Dari Perspektif Hukum Pidana/Korupsi)", Makalah, Pertanggungjawaban Kebijakan Ditinjau Dari Hukum, Lembaga Pengembangan Fraud Auditing, Hotel Bumi Karsa Bidakara, Jakarta, Tanggal 11 Mei 2010, p. 11.

[11] Aldilla A., Disparitas Pidana (Disparity Of Sentencing) Dalam Putusan Pengadilan Terhadap Tindak Pidana Narkotika (Studi Kasus Di Pengadilan Negeri Jakarta Pusat), (Jakarta: Universitas Indonesia, 2013), p. 41.

[12] Muladi \& Barda N.A., Teori \& Kebijakan Pidana, (Bandung: Alumni, 1998), p. 53.

[13] Irene W., Kebijakan Kriminal Dalam Penerapan Pidana Tambahan Pembayaran Uang Pengganti (Studi Kasus Perkara an. Ahmad Dadang, dkk), (Jakarta: Universitas Indonesia, 2013), p. 89.

[14] Henry C.B., Black's Law Dictionary, (St. Paul: West Publishing. Co, 1991), p. 951.

[15] Cassia S., How Do Judges Decide? The Search For Fairness And Justice In Punishment, (California: SAGE Publications Inc), p. 129.

[16] Ibid.

[17] Harkristuti H., "Rekonstruksi Konsep Pemidanaan: Suatu Gugatan Terhadap Proses Legislasi \& Pemidanaan di Indonesia”, Pidato Pengukuhan Guru Besar Tetap Dalam Ilmu Hukum Pidana, FH-UI, Balai Sidang UI, Depok Tanggal 8 Maret 2003, p. 7.

[18] Putusan Nomor: 1195/Pid.B/2010/PN.Jkt.Sel., tanggal 19 Januari 2011.

[19] Putusan Nomor: 06/Pid/TPK/2011/PT.DKI, tanggal 29 April 2011.

[20] Putusan Nomor: 1198 K/Pid.Sus/2011, tanggal 20 Juli 2011.

[21] Putusan Nomor 19/Pid.Sus/TPK/2011/PN.Bdg., tanggal 22 Agustus 2011.

[22] Putusan Nomor 2407 K/Pid.Sus/2011, tanggal 21 Februari 2012.

[23] Putusan Nomor: 54/Pid.B/TPK/2012/PN.JKT.PST., Tanggal 10 Januari 2013.

[24] Putusan Nomor: 1616 K/Pid.Sus/2013 Tanggal 20 November 2013.

[25] Putusan Nomor 1522/Pid.B/2000/PN.JKT.PST tanggal 13 Maret 2002. 
[26] Putusan Nomor 78/PID/2002/PT.DKI tanggal 12 Agustus 2002.

[27] Putusan Nomor 1900 K/PID/2002 tanggal 23 September 2004.

[28] Putusan Nomor 04/Pid.B/2007/PN.Jkt.Pst. tanggal 23 Juli 2007.

[29] Putusan Nomor 09/Pid/TPK/2007/PT.DKI., tangga 17 November 2007.

[30] Putusan Nomor 39 PK/Pid.Sus/2009.

[31] Chairul H., Dari Tiada Pidana Tanpa Kesalahan Menuju Kepada Tiada Pertanggungjawaban Pidana Tanpa Kesalahan, (Jakarta: Kencana, 2008), p. 158.

[32] Harkristuti H., Op. cit.,p. 9.

[33] Andrew A., Sentencing and Criminal Justice, 4rd Ed., (Cambridge: Cambridge University Press, 2005), p. 73

[34] Nigel W., Sentencing in A Rational Society, (London: Pelican Book, 1972), pp. 14-15.

[35] Andi H., Asas-Asas Hukum Pidana di Indonesia \& Perkembangannya, (Jakarta: Sofmedia, 2012), p. 37.

[36] C. Ray J., Crime Prevention Through Environmental Design, (London: SAGE Publication, 1977), pp. 18.

[37] Mahmud M., Criminal Policy, Pendekatan Integral Penal Policy dan Non-Penal Policy Dalam Penanggulangan Kejahatan Kekerasan, (Medan: Pustaka Bangsa Press, 2008), p. 88

[38] Jan R., Hukum Pidana, Komentar Atas PasalPasal Terpenting dari KUHPidana Belanda dan Padanannya Dalam KUHIndonesia, (Jakarta: Gramedia Pustaka Utama, 2003), p. 14.

[39] Tata W. \& Hery F., Perbedaan Pendapat Dalam Putusan Pengadilan, (Yogyakarta: Pustaka Yustisia, 2011), p. 82.

[40] Ibid., pp. 90-92.

[41] Muladi \& Barda N.A., Op. cit., p. 56.

[42] M. Yahya H., Pembahasan Permasalahan dan Penerapan KUHAP Pemeriksaan Sidang Pengadilan, Banding, Kasasi, \& PK, Edisi Kedia, (Jakarta: Sinar Grafika, 1985), p. 279.

[43] Russell, Peter H., \& David M.O., Judicial Independence In The Age Of Democracy, Critical perspectives from around the world, (Toronto: Constitutionalism \& Democracy Series, McGraw-Hill, 1985), p. 12.

[44] Sudikno M., "Relevansi Pengaruh Etika Profesi Bagi Kemandirian Kekuasaan Kehakiman", Makalah pada Seminar 50 Tahun Kekuasaan Kehakiman di Indonesia, Diselenggarakan oleh FH-UGM, Depok Tanggal 26 Agustus 1995, p. 2.

[45] Paulus E.L., "Kemandirian Kekuasaan Kehakiman Dalam Konteks Pembagian Kelkuasaan dan Pertanggungan Jawab Politik, Makalah, Seminar Hukum Nasional Ke-VII Reformasi Hukum Menuju Masyarakat Madani,
BPHN Departemen Kehakiman, 1999, pp. 156170.

[46] Austin L., The Framework of Judicial Sentencing, (Cambridge: Cambridge University Press, 1997), p. 29.

[47] Howard A., Discretionary Justice, An Introduction to Discretion in Criminal Justice, (Springfield-Amerika Serikat: Charles C. Thomas Publisher, 1984), p. 3

[48] Soerjono S., Faktor-Faktor Mempengaruhi Penegakan Hukum, (Jakarta: RajaGrafindo Persada, 2002), p. 15.

[49] Paul B.W., Supervision in The Administration of Justice Police, Coorection, Courts, (Springfield: Charles \& Thomas, 1965), p. 129.

[50] Carl J.F., et.al Raisul M., Filsafat Hukum Perspektif Historis, (Bandung: Nusa Media, 2010), p. 168

[51] G.W. Paton, A Text-Book of Jurisprudence, (London: Oxford University Press, 1964), p. 69.

[52] Andrew V.H., Kay A.K., \& Michael T., The Sentencing Comission \& Its guidelines, (Boston: Northeastern University Press,1987) p. 7.

[53]http://www.ussc.gov/Guidelines/2012_Guidelines/ Manual_PDF/Sentencing_Table.pdf, diakses tanggal 21 September 20021.

[54] Pedoman Pemidanaan di United States of America, Sentencing Table (In Months Imprisonment).

[55] Michael T., Sentencing Matters, (Oxford: Oxford University Press, 1996), p. 41

[56] Harkristuti H., Op. cit., p. 24.

[57] Ibid., p. 25. 